\title{
Latest updates on chronic delta hepatitis
}

\author{
Kronik delta hepatiti ile ilgili son güncellemeler
}

\author{
Kendal YALÇIN, Elif Tuğba TUNCEL, Feyza GÜNDÜZ
}

\begin{abstract}
The hepatitis D virus was shown for the first time in 1977 by Rizzetto and friends. The HDV genome and the cloning of sequence were made in 1986. HDV is the first animal virus with circular RNA genome which is seen only in plant viruses. HDV is an RNA virus with the known smallest viral genome in animal viruses. It is classified as Deltavirus genius depending on the type of virus by ICTV in 1996. HDV is classified as the sole example of delta virus in this genus.

Chronic delta hepatitis is the least common form of chronic viral hepatitis due to hepatotropic viruses. In contrast, the virus is highly pathogenic and can cause serious consequences. Today, prevalance of delta hepatitis has been shown to decrease. However, the delta hepatitis continues to be an important health problem in some parts of the world. In our country, especially in Eastern and Southeastern Anatolia, hepatitis D is a serious and important health problem and still maintains its importance as a health problem. In Turkey, still there is a significant number of patients with HDV infection despite a documented decrease in HDV infection.

The recommended treatment for chronic HDV infection in the current guidelines is the treatment with peginterferon alfa given once a week for 48 weeks. Treatment is indicated for patients who has compensated disease with active infection. In patients with advanced form of disease, the expected benefits of the peginterferon must be well balanced against the potential side effects and low response rate. An oral antiviral can be recommended in patients who has high levels of serum HBV DNA. In contrast, the control of HBV infecion does not seem to change the natural history of HDV related disease.
\end{abstract}

Keywords: Delta hepatitis, Treatment, Prognosis

Kendal Yalçın (『), Elif Tuğba Tuncel

Sub-department of Gastroenterology and Hepatology, Department of Internal Medicine, Dicle University, School of Medicine, Diyarbakur, Turkey

e-mail:kendalyalcin@hotmail.com

Feyza Gündüz

Sub-department of Gastroenterology and Hepatology, Department of Internal Medicine, School of Medicine, Marmara University Education and Research Hospital, İstanbul, Turkey

\section{ÖZ}

Hepatit D virüsü ilk kez Rizzetto ve arkadaşları tarafından 1977 yılında gösterilmiştir. HDV genomunun klonlanması ve sekanslanması ise 1986 yılında yapılmıştır. HDV sadece bitki virüslerinde görülen sirküler RNA genomuna sahip ilk hayvan virüsü ve hayvan virüsleri içinde de bilinen en küçük viral genoma sahip RNA virüsüdür. 1996 yılında ICTV tarafindan Deltavirus cinsine bağlı bir virüs olarak sınıflandırılmıştır. HDV, delta virüs cinsi içinde, bu cinsin tek örneği olarak sınıflandırılmıştır.

Kronik delta hepatiti, hepatotrop virüslere bağlı kronik viral hepatitlerin en seyrek görüleni, buna karş1lık yüksek derecede patojenik ve sonuçları itibarı ile en ciddi seyredenidir. Günümüzde delta hepatit prevalansının azaldığı, özellikle İtalya'dan yapılan çalışmalarda gösterilmişse de, dünyanın bazı bölgelerinde delta hepatit önemli bir sağlık sorunu olmaya devam etmektedir. Ülkemizde özellikle Doğu ve Güneydoğu Anadolu'da delta hepatit önemli ve ciddi bir sağlık sorunu olarak hala önemini korumaktadır. Son y1llarda Türkiye genelinde HDV infeksiyonu azalmasına rağmen hala ciddi oranlarda HDV pozitifliği devam etmektedir.

Kronik HDV hastalığı için güncel kılavuzlarında önerdiği ve etkinliği kanıtlanmış tek tedavi şekli, 48 hafta süreyle haftada bir verilen peginterferon alfa tedavisidir. Aktif kompanse HDV hastalığı olan hastalarda tedavi endikedir. İlerlemiş hastalığı olan hastalarda, tedavinin beklenen yararları peginterferonun sirotik hastalarda potansiyel yan etkilerine ve düşük yanıt oranına karşı dengelenmelidir. Anlaml1 HBV DNA serum titreleri bulunan hastalarda bir hepatit B virüs antiviralinin kullanılması önerilebilir ama HBV'nin kontrol altına alınması HDV karaciğer hastalığının doğal seyrini değiştiriyor gibi görünmemektedir.

Anahtar kelimeler: Hepatit D, Tedavi, Prognoz

\section{Introduction}

Hepatitis D virus (HDV) is a distinctive human pathogen, which depends on hepatitis B virus (HBV) for infection [1]. 
Patients co-infected with HDV and HBV have a higher rate of progression of severe liver disease and cirrhosis than patients infected with only HBV.

\section{Virology}

HDV is a unique RNA pathogen which proliferates by 'rolling circle mechanism' that is unknown in other animal viruses. HDV is dependent on the presence of HBV to cause infection and can replicate in patients who have surface antigen of the hepatitis B (HBsAg) virus. HBsAg is required function for HDV. Infection with HDV does not correlate with HBV DNA level. HDV genome contains one ribosome and codes two proteins: S-HDAg and L-HDAg. S-HDAg supports replication and L-HDAg provides virion packaging while inhibiting the replication [2].

Contrary to conventional RNA viruses, HDV cannot code its own replication and entirely depends on host replication mechanism for its synthesis [2]. HDV replicates in the liver cell with rolling circle mechanism, using DNA dependent RNA polymerase I, II and III [3]. Briefly, HDV replication starts with viral attachment. Delta virus, similar to $\mathrm{HBV}$, connects to hepatocyte membrane with L-HBsAg and enters. After the virus peels off in cytoplasm, remaining ribonucleoprotein passes to nucleus. Genome heads towards the nucleus, with the help of nuclear localization signals located in delta antigen. Transcription and replication of HDV genome, display a unique property. Finally, virus leaves the cell after viral assembly is completed. Leaving the host hepatocyte requires $\mathrm{HBsAg}$.

\section{Epidemiology}

There are nearly 350 million chronic HBV carriers worldwide [4]. Approximately 5\% of HBsAg carriers have HDV infection. Nearly 15 million of these cases have serological evidences of HDV exposure [5-7]. Prevalence rates show differences in Europe; Eastern Europe rates range between 14\% and 39\%, while Central Europe and Western Europe have rates lower than $6 \%[8]$.

Current HDV infection rate of HBsAg carriers is nearly $10 \%$ in Italy [9] and roughly $11 \%$ in Turkey [10]. However, HDV is still responsible for nearly half of liver cirrhosis and hepatocellular carcinoma cases in Southeastern Turkey [11]. Latest studies from Turkey indicate HDV prevalence between $0.9-16.2 \%$ in asymptomatic HBV carriers, 2.5$21.8 \%$ in acute HBV infections, 9-51.7\% in chronic liver disease patients and $23-74 \%$ of cirrhosis patients [10,12-14].

\section{Transmission}

Fundamental principles of protection against HDV are vaccination against Hepatitis $\mathrm{B}$ in uninfected or unimmunized patients, and education for risk factors such as sexual transmission and use of contaminated needles. HDV is transmitted by parenteral route [15], and potentially sexually transmitted $[16,17]$. Perinatal transmission and patients who undergo hemodialysis are low because of routine testing for $\mathrm{HBV}$, and this varies depending on the country.

\section{Hepatitis D virus genotypes}

Eight different HDV genotypes were identified [19]. Genotype 1 is the most commonly seen genotype worldwide and is commonly seen in Europe, Middle East, North America, Africa and India. It has been shown that the genotype of delta virus seen in Turkey is genotype 1 as well [20]. While Genotype 2 is common in Far East, Genotype 3 is only found in Northern countries of South America. Genotype 4 is found in Taiwan and Japan and Genotype 5-8 are identified in African patients, also they are in relation with A-E genotypes of HBV. Genotype $1 \mathrm{HDV}$ infection has a versatile clinical course and Genotype 2 infection is generally characterized by a slowly progressive disease. Genotype 3 is the most different and aggressive genotype and generally causes a fulminant disease via microvesicular steatosis and eosinophilic degeneration in a cytopathic noninflammatory liver [21].

\section{Pathogenesis}

Most of the acute HBV/HDV co-infections are healed with the clearing of HBV. Typically, an HDV super-infection over a preexisting $\mathrm{HBV}$ infection becomes chronic. While the indicators for $\mathrm{HBV}$ replication are positive in a coinfection, they are often negative in a super-infection.

The pathogenesis of delta hepatitis is not fully understood. HDV affiliated hepatocyte damage is a result of immunologic response. In these cases, there is proliferation in CD4+ T cells and in the contrary there is a weakening in the CD8+ T-cell response. Fulminant delta hepatitis with microvesicular steatosis cases are noticed in Northern side of South America, and another feature that attracts attention is the lack of inflammation.

HDV's transmission risk is determined by the HBsAg status of the person [22]. HDV cannot infect HBsAg negative people. $95 \%$ of acute $\mathrm{HBV} / \mathrm{HDV}$ co-infection cases result in clearance of $\mathrm{HBV}$, same with conventional acute hepatitis B [23]. Hepatitis D cannot continue its existence after the HBV elimination and as a result, hepatitis D has a selflimiting attribute. 


\section{Diagnosis}

\section{Identifying antibodies against hepatitis D antigen}

All HBsAg positive patients with liver disease and especially HBsAg positive drug users must be tested in terms of antiHD [24]. Total anti-HD is commercially available. Anti-HD appears after the first couple weeks of infection and stays at high levels in HBsAg carriers with progressed chronic HDV infection [25]. IgM anti-HD is the indicator of liver damage related to $\mathrm{HDV}$.

\section{Identifying RNA of hepatitis D virus}

Patients with positive anti-HD must be tested for serum HDV RNA levels. PCR is the most effective method [2629]. HDV RNA levels do not correlate with the severity of infection but can be useful for evaluating the treatment efficiency [28]. The best evidence of active infection is HDV RNA levels. HDV RNA positive patients must be tested for underlying liver diseases.

\section{Natural course and clinical characteristics}

In a patient with Hepatitis $\mathrm{B}$ infection, delta infection usually presents itself in two ways: Patient receives HDV with hepatitis $\mathrm{B}$ virus simultaneously (Co-infection) or delta infection gets combined with preexisting hepatitis B infection afterwards (Super-infection). Both infections forms have different clinical presentations and natural courses.

\section{Acute delta hepatitis (Co-infection)}

$\mathrm{HBV} / \mathrm{HDV}$ co-infection generally results in an acute, selflimiting hepatitis [7]. It can be distinguished from acute hepatitis B by biphasic peak aminotransferase elevation. Transaminases display two elevations within 2-5 week interval. Generally the first elevation is associated with the HBV infection while the second one with the HDV infection. The chronicity risk of a co-infection is roughly $2-7 \%$.

\section{Hepatitis D virus super-infection}

HDV super-infection generally results in a severe hepatitis in HBsAg carriers. Clinically acute hepatitis are seen in $50-70 \%$ of super-infections that are developed in HBsAg carriers. The bipashic course that is seen in co-infection may not occur in super-infection. In most HDV patients, HDV disease becomes chronic; and in most cases (around 90\%) it leads to cirrhosis. Chronic disease has a more progressive and severe course than HBV mono-infection [31]. In patients with $\mathrm{HBV} / \mathrm{HDV} / \mathrm{HCV}$ triple infection, $\mathrm{HDV}$ is generally the dominant virus and inhibits the replication of both viruses. HIV infected patients with HDV has a higher risk to develop cirrhosis.

Primary HDV super-infection leads to severe hepatitis [18].
If the patient's HBsAg status is unknown, Hepatitis D with super-infection can be similar to acute hepatitis B infection or it can mimic the reactivation of the underlying chronic hepatitis B virus infection [18].

\section{Chronic hepatitis D virus infection}

A progress towards chronic hepatitis D after super-infection is common [18]. HDV generally inhibits HBV replication. However, it takes a more severe and progressive route that goes towards cirrhosis in patients with $\mathrm{HBV}$ or hepatitis $\mathrm{C}$ virus (HCV) that leads to liver failure and death. A range of autoantibodies can accompany the chronic hepatitis delta infection, the most specific ones are 'liver-kidney' (LKM antibody, type 3) antibodies. Pathogenic roles of LKM and other autoantibodies in delta hepatitis are unknown. Unlike HBV, it only infects the hepatocyte and extrahepatic virus replication is not seen. In acute HDV infection, microvesicular steatosis and granular eosinophilic necrosis are commonly seen.

A European research published in 2000 showed that $\mathrm{HCC}$ risk was 3 times greater in patients with HDV than patients with HBV mono-infection [22,31]. But in other studies it is not clearly seen that HDV provides any meaningful increase to this risk [32]. In another study, it was shown that HBV/HDV co-infection was with a higher risk of hepatocellular carcinoma than mono-infected with HBV patients or uninfected people [33]. Drug users are under the risk of both $\mathrm{HDV}$ and $\mathrm{HCV}$, furthermore, $\mathrm{HBV} / \mathrm{HDV} / \mathrm{HCV}$ triple infection is commonly seen in these patients. Chronic hepatitis D seems as it takes an accelerated course in patients with HIV.

\section{Treatment}

Developing antiviral treatment against HDV is insufficient for these reasons:

- Absence of a specific enzymatic target,

- HDV's diminishing prevalence in the Western World,

- Need of attention to two viral targets because of infection's synchronous nature.

First research about standard interferon showed that 6-12 months of treatments decrease the liver enzymes in roughly $20-25 \%$ of patients with HDV [34]. With the peginterferon alfa treatment, up to $47 \%$ high virologic response rates (HDV RNA serum that can not be identified 6 months after the end of treatment) are observed [35]. In patients treated with antiviral drugs against $\mathrm{HBV}$, a significant virologic or clinical recovery of HDV disease is not observed. 


\section{Pretreatment Response and Toxicity Predictors}

Low basal HBsAg and HDV RNA levels can predict response to treatment $[28,29]$. Genotype $1 \mathrm{HDV}$ can be affiliated with a reduced response [36]. It is shown that HDV RNA kinetic indicates the response throughout the treatment [37]. IgM anti-HD reduction can indicate a response to antiviral treatment [38].

\section{Treatment of hepatitis delta and HIV co-infection}

Treatment should be always considered based on the high probability of HDV's poor prognosis. Because of lower effectiveness and high toxicity with peginterferon in patients co-infected with Hepatitis B virus (HBV)/HIV [39] using peginterferon is advised only on HBV/HIV co-infected patients who have positive response predictors and do not get antiretroviral treatment [40]. Similarly, treatment only should not be considered in patients co-infected with HBV/ $\mathrm{HDV} / \mathrm{HIV}$ if the risk of complications in the liver is greater than the benefits of peginterferon treatment [36].

\section{Liver transplantation}

End stage liver disease is an indication for liver transplantation because of its excellent results [41,42]. Hepatitis B immunoglobulin and its prophylaxis with antiviral treatment should be given to all transplanted patients inorder to prevent reinfection.

\section{Current treatment strategies}

Generally, it is suggested that HDV-infected people with a compensated disease should be treated with peginterferon for 48 weeks[5,43]. Use of oral antiviral agents can be suggested for patients with significant HBV DNA levels. Extending the treatment beyond 12 months can be effective for patients with partial virologic and biochemical responses.

\section{New treatments}

Hepatitis D antigen undergoes various post-translational procedures such as prenylation, acetylation, phosphorylation and methylation that present new potential targets for new treatments [5]. Prenylation has a key role in HDV morphogenesis. It is shown that prenylation inhibitors cause clearance of HDV RNA [44]. Studies about gene treatments made with anti-sense oligonucleotides which inhibit viral gene expression and replication without affecting host protein synthesis, or ribosomes that cause the division of target RNA by specifically binding with the target RNA's molecules, are still ongoing. Little interfering RNAs that target the messenger RNA, which codes Hepatitis D antigen, can effect the HDV replication [45].
Primary care physicians who diagnose HDV infection in patients with HBV infection should refer patients to a hepatologist because of the lack of available data and consensus on the optimum treatment procedure and period based on solid evidence.

\section{Vaccination}

Hepatitis B vaccination is an effective prophylaxis against $\mathrm{HDV}$. Lifelong protection against HBV provides protection against HDV [46]. HBsAg carriers should be informed about the risks of super-infection from carriers co-infected with HDV, and should be educated on the subjects of protective/ preventive practices.

\section{References}

1. Rizzetto M. Critical care options. In: Afdhal NH, Zeuzem S, editors. Clinical Care Options, Hepatitis, Practice, Hepatitis Delta virus. Last Reviewed: 6/23/14 (What's New).

2. Taylor JM. Replication of the hepatitis delta virus RNA genome. Adv Virus Res 2009;74:103-21.

3. Greco-Stewart VS, Schissel E, Pelchat M. The hepatitis delta virus RNA genome interacts with the human RNA polymerases I and III. Virology 2009;386:12-5.

4. World Health Organization. Hepatitis B fact sheet 204 (updated July 2013). Available at: http://www.who.int/ mediacentre/factsheets/fs204/en/index.html. Accessed June 16, 2014.

5. Hughes SA, Wedemeyer H, Harrison PM. Hepatitis delta virus. Lancet 2011;378:73-85.

6. Rizzetto M, Ciancio A. Epidemiology of hepatitis D. Semin Liver Dis 2012;32:211-9.

7. Farci P. Delta hepatitis: an update. J Hepatol 2003;39(suppl 1):S212-S219.

8. Genné D, Rossi I. Hepatitis delta in Switzerland: a silent epidemic. Swiss Med Wkly 2011 Mar 18.

9. Stroffolini T, Almasio PL, Sagnelli E, Mele A, Gaeta GB. Italian Hospitals' Collaborating Group. Evolving clinical landscape of chronic hepatitis B: a multicenter Italian study. J Med Virol 2009;81:1999-2006.

10. Değertekin H, Yalcin K, Yakut M, Yurdaydin C. Seropositivity for delta hepatitis in patients with chronic hepatitis B and liver cirrhosis in Turkey: a meta-analysis. Liver Int 2008;28:494-8.

11. Bahcecioglu IH, Aygun C, Gozel N, Poyrazoglu OK, Bulut Y, Yalniz M. Prevalence of hepatitis delta virus (HDV) infection in chronic hepatitis B patients in eastern Turkey: still a serious problem to consider. J Viral Hepat 2011;18:518-24.

12. Degertekin H, Yalcin K, Yakut M. The prevalence of hepatitis delta virus infection in acute and chronic liver diseases in Turkey: An analysis of clinical studies. Turk J Gastroenterol 2006; 17:25-34.

13. Yalçın K, Yalçın S, Büyükbayram H, et al. Kronik HDV infeksiyonlu hastalarda serum HBV DNA, HDV RNA düzeyleri ve histolojik bulguların hastalığın klinik evreleriyle 
ilişkisi: prospektif klinik çalıșma. 25. Ulusal Gastroenteroloji Haftas1, 2008.

14. Yalçın K, Değertekin H. Etiology and clinical aspects of liver cirrhosis in Diyarbakır. National congress of Gastroenterology, Turkey, 2002.

15. Bonino F, Caporaso N, Dentico P, et al. Familiar clustering and spreading of hepatitis delta virus infection. J Hepatol 1985;1:221-6

16. Wu JC, Chen CM, Sheen IJ, et al. Evidence of transmission of hepatitis D virus to spouses from sequence analysis of the viral genome. Hepatology 1995;226:1656-60.

17. Rosenblum L, Darrow W, Witte J, et al. Sexual practices in the transmission of hepatitis B virus and prevalence of hepatitis delta virus infection in female prostitutes in the United States. JAMA 1992;267:2477-81.

18. Smedile A, Rizzetto M, Gerin JL. Advances in hepatitis D virus biology and disease. Prog Liver Dis 1994;12:157-75.

19. Dény P. Hepatitis delta virus genetic variability: from genotypes I, II, III to eight major clades? Curr Top Microbiol Immunol 2006;307:151-71.

20. Shakil AO, Hadziyannis S, Hoofnagle JH, et al. Geographic distribution and genetic variability of hepatitis delta virus genotype I. Virology 1997;234:160-7.

21. Alvarado-Mora MV, Romano CM, Gomes-Gouvêa MS, Gutierrez MF, Carrilho FJ, Pinho JR. Dynamics of hepatitis $\mathrm{D}$ (delta) virus genotype 3 in the Amazon region of South America. Infect Genet Evol 2011;11:1462-8.

22. Rizzetto M. Hepatitis D: thirty years after. J Hepatol 2009;50:1043-50

23. McMahon BJ, Alward WL, Hall DB, et al. Acute hepatitis $B$ virus infection: relation of age to the clinical expression of disease and subsequent development of the carrier state. $\mathrm{J}$ Infect Dis 1985; 151:599-603.

24. Lok AS, McMahon BJ. Chronic hepatitis B: update 2009. Hepatology 2009;50:661-2.

25. Negro F, Rizzetto M. Diagnosis of hepatitis delta virus infection. J Hepatol 1995;22(1 suppl):136-9.

26. Smedile A, Niro MG, Rizzetto M. Detection of serum HDVRNA by RT-PCR. Methods Mol Med 2004;95:85-93.

27. Le Gal F, Gordien E, Affolabi D, et al. Quantification of hepatitis delta virus RNA in serum by consensus real-time PCR indicates different patterns of virological response to interferon therapy in chronically infected patients. J Clin Microbiol 2005;43:2363-9.

28. Schaper M, Rodriguez-Frias F, Jardi R, et al. Quantitative longitudinal evaluations of hepatitis delta virus RNA and hepatitis B virus DNA shows a dynamic, complex replicative profile in chronic hepatitis B and D. J Hepatol 2010;52:65864.

29. Mederacke I, Bremer B, Heidrich B, et al. Establishment of a novel quantitative hepatitis D virus (HDV) RNA assay using the Cobas TaqMan platform to study HDV RNA kinetics. J Clin Microbiol. 2010;48:2022-9.

30. Pascarella S, Negro F. Hepatitis D virus: an update. Liver Int 2011;31:7-21.

31. Fattovich G, Giustina G, Christensen E, et al. Influence of hepatitis delta virus infection on morbidity and mortality in compensated cirrhosis type B. The European Concerted Action on Viral Hepatitis (Eurohep). Gut 2000;46:420-6.

32. Cross TJ, Rizzi P, Horner M, et al. The increasing prevalence of hepatitis delta virus (HDV) infection in South London. $\mathbf{J}$ Med Virol 2008;80:277-82.

33. Ji J, Sundquist K, Sundquist J. A population-based study of hepatitis D virus as potential risk factor for hepatocellular carcinoma. J Natl Cancer Inst 2012;104:790-2.

34. Niro GA, Rosina F, Rizzetto M. Treatment of hepatitis D. J Viral Hepat 2005;12:2-9.

35. Gunsar F, Akarca US, Ersoz G, et al. Two-year interferon therapy with or without ribavirin in chronic delta hepatitis. Antivir Ther 2005;10:721-6.

36. Calle Serrano B, Manns MP, Wedemeyer H. Hepatitis delta and HIV infection. Semin Liver Dis 2012;32:120-9.

37. Castelnau C, Le Gal F, Ripault MP, et al. Efficacy of peginterferon alpha- $2 b$ in chronic hepatitis delta: relevance of quantitative RT-PCR for follow-up. Hepatology 2006;44:728-35.

38. Mederacke I, Yurdaydin C, Dalekos GN, et al. Anti-HDV immunoglobulin $\mathrm{M}$ testing in hepatitis delta revisited: correlations with disease activity and response to pegylated interferon- 2a treatment. Antivir Ther 2012;17:305-12.

39. Di Martino V, Thevenot T, Colin JF, et al. Influence of HIV infection on the response to interferon therapy and the long-term outcome of chronic hepatitis B. Gastroenterology 2002;123:1812-22

40. Soriano V, Puoti M, Peters M, et al. Care of HIV patients with chronic hepatitis B: updated recommendations from the HIVHepatitis B Virus International Panel. AIDS 2008;22:1399410 .

41. Samuel D, Zignego AL, Reynes $\mathrm{M}$, et al. Long-term clinical and virological outcome after liver transplantation for cirrhosis caused by chronic delta hepatitis. Hepatology 1995;21:333-9.

42. Burra P, Germani G, Adam R, et al. Liver transplantation for HBV-related cirrhosis in Europe: an ELTR study on evolution and outcomes. J Hepatol 2013;58:287-96.

43. Lamers MH, Kirgiz ÖÖ, Heidrich B, Wedemeyer H, Drenth JP. Interferon- for patients with chronic hepatitis delta: a systematic review of randomized clinical trials. Antivir Ther 2012; 17:1029-37.

44. Bordier BB, Ohkanda J, Liu P, et al. In vivo antiviral efficacy of prenylation inhibitors against hepatitis delta virus. Clin Invest 2003;112:407-14.

45. Chang J, Taylor JM. Susceptibility of human hepatitis delta virus RNAs to small interfering RNA action. J Virol 2003;77:9728-31.

46. Fiedler M, Kosinska A, Schumann A, et al. Prime/boost immunization with DNA and adenoviral vectors protects from hepatitis D virus (HDV) infection after simultaneous infection with HDV and woodchuck hepatitis virus. J Virol 2013;87:7708-16. 